EDITORIAL

\title{
A REBEn E O SABER NA ENFERMAGEM
}

Na corporificação de um saber na enfermagem, como este se desenvolve no âmbito da sociedade brasileira, a REBEn vem atuando, não só como veículo de divulgação, mas como estimulador dessa produção de conhecimento específico.

Pelas viscissitudes porque tem passado esta publicação, ao longo de suas seis décadas de existência e, pelo esforço que invariavelmente, têm desenvolvido seus responsáveis para editá-la trimestralmente, com regularidade, esta Revista se identifica, também, de algum modo, com a própria imagem da profissão de enfermagem, em sua permanente busca para crescer $e$ aprimorar-se, visando, assim, melhor servir às finalidades para as quais foi criada. $O$ volume das análises de que têm sido objeto os trabalhos aqui publicados, dá a medida de sua importancia $e$ significação na literatura profissional produzida neste país.

Com o aprofundamento crítico desses estudos, ensaia-se, até mesmo, o que se poderia chamar de uma iniciante sociologia do conhecimento da enfermagem, tão ao gosto dos analistas que pretendem considerar as categorias do pensamento como produtos da sociedade, em suas diferentes fases evolutivas e sujeitas a determinantes econômicos.

Por outro lado, há os que se preocupam com a identificação desses saberes, enquanto estes possam caracterizar-se como saberes científicos ou pré-científicos, superiores ou ingênuos $e$, como se dá esse inter-relacionamento enquanto saberes que, utilizando a metodologia cientifica, visam "explicar" o fenômeno e buscam responder os "porquês" ou, procuram apenas "compreender" e se contentam no "para que fim" $e$ influenciam na configuração teleologica da nascente ciência de enfermagem.

Há certamente ainda aqueles que, com presteza, indagam como este acervo vem se incorporando à prática profissional e tem, por conseguinte, contribuído para melhorar os niveis de saúde das comunidades, ou para ajudar na recuperação daquelas pessoas que necessitam de cuidados especificos e em diferentes niveis de complexidade.

Indaga-se, também, o conhecimento ou saber enquanto fonte de poder especializado, enquanto inerente ao agir profissional autônomo $e$, por isto mesmo responsável $e$, como este poder se exerce, em niveis variados e em diferentes pontos da rede social, definindo não só as relações inter e intraprofissionais, mas a própria inserção profissional nas instituições de saúde.

Estudada, analisada, criticada, aplaudida e reclamada a REBEn tem se constituido como uma das mais importantes fontes de conhecimento na enfermagem.

Em sua nova linha editorial, pretende-se privilegiar, sempre que possivel, a divulgação de trabalhos que resultem de pesquisas, visando com isto, de um lado estimular o desenvolvimento científico e tecnológico da profissão $e$, de outro, difundir essas informações, segundo aconselha o CNPq que nos prestigia com o patrocínio dos dois primeiros números da REBEn de 1984, como uma forma concreta de socializar $e$ transferir o saber adquirido $e$ acumulado de modo que este se torne cada vez mais, um instrumento na vida de muitos e melhore assim sensivelmente a causa da saúde e da enfermagem. 